Nina Biehal, SWRDU, B Block, Alcuin College, University of York, Heslington, York, YO10 5DD, UK

Foster fathers: their experiences and contributions to fostering

By: Kate Wilson, Rachel Fyson and Simon Newstone

Kate Wilson is professor of social work in the Centre for Social Work at the University of Nottingham. Rachel Fyson is a lecturer in the same department. Simon Newstone works as a freelance child care trainer and consultant in East Sussex.

Address for correspondence: Professor Kate Wilson, Centre for Social Work, School of Sociology and Social Work, University of Nottingham, University Park, Nottingham, NG7 2RD Telephone: 01159515411

\begin{abstract}
The paper reports some of the findings of an exploratory study which looks at foster fathers' experiences of fostering and discusses their routes into foster care and their perspectives on their roles and tasks. The study collected quantitative and qualitative data by approaching all foster fathers registered with a single independent fostering agency based in southeast England. They were asked about their personal and professional attributes, and their experiences of and views concerning the role of foster father. The study discusses the foster fathers' motivation to foster, and argues that what they see as its positives and drawbacks, and how it fits into their own family lives, are all relevant to improving service recruitment, delivery and retention. The study produced some evidence about the distinctive and positive contribution which foster fathers see themselves making to the lives of the children they foster. Further research is needed to refine our knowledge of what this contribution may be. Such knowledge could potentially develop our understanding of the roles of fathers in child development
\end{abstract}


more generally as well as fine-tuning practice in matching what particular placements have to offer to the needs of individual children. 


\title{
Foster fathers: their experiences and contributions to fostering
}

\author{
Kate Wilson, Rachel Fyson and Simon Newstone
}

\section{Introduction}

This article reports some of the findings of a study which looked at foster fathers' experiences of fostering. The study was prompted by a recognition of the potentially important role which foster fathers play in the lives of foster children, and concern at the relative lack of attention paid to them by agencies, social workers and researchers. Although limited in scope, we hope that this study will provide a first step in clarifying the motivations, roles and tasks of these largely unstudied and silent participants in foster care, so that their contribution to foster care can be better understood and the benefits exploited.

Two relatively recent articles (Gilligan, 2000; Newstone, 2000) have highlighted the paucity of research which addresses the role of foster fathers; and a number of researchers and policy makers have stressed the importance of the foster father's role without being able to draw on much research evidence to support or clarify these claims (e.g. Fanshel and Shin 1978; Inch, 1999; Triseliotis,2000). Many major studies of fostering, including that undertaken by one of the present authors (Sinclair, Gibbs \& Wilson \& 2004), have shown not a little gender blindness when appraising foster care services. For example, the latter study, acknowledges that foster fathers are largely invisible, and comments:

'... as will be apparent from the above, we have slipped from talking about foster families to talking about the 'main carer' (in practice almost always a woman.) While this book deals with family issues, it reports them through the eyes of female carers.'(Sinclair, Gibbs \& Wilson, 2004, p. 23)

By contrast, however, Hojer - in a study which examined the impact of fostering upon the dynamics of host families in Sweden - suggests that foster fathers have featured more prominently in recent years. In the qualitative part of her study she interviewed both foster fathers and foster mothers, and found that, as well as taking an active part in the everyday work of fostering, men were just as interested and committed as their partners when it came to talking about their contributions (Hojer, 2004, p.45). 
The above discussion suggests an ambitious agenda, which we can only start to address in the exploratory study presented here. In this article, we make a beginning by drawing on the findings of the study to describe some of the key characteristics of the foster fathers in the sample, and discuss their routes into foster care and their perspectives on their roles and tasks. In a subsequent article we report on their experiences of training, in particular in relation to that on Safer Caring - the guidance and practice for foster carers looking after children who may have been abused, first developed as a systematic focus of training about a decade ago by Fostering Network.

\section{The study}

The study collected quantitative and qualitative data by approaching all foster fathers registered with a single independent fostering agency based in southeast England. The agency which was established in 1990 has over 200 children and young people in family placements. Children are predominantly of school age, with about half being adolescents, and there is a mix of short-term and permanent placements. Many of the young people placed present challenging behaviours. The agency was chosen in part because it was known to have a particular interest in encouraging and supporting the involvement of foster fathers, a focus which we hoped would increase the response rate to our questionnaires and interviews. The questionnaire which was distributed via the agency newsletter asked about the personal and professional attributes of respondents, and their experiences of and views concerning the role of foster father. The drawbacks of taking the sample from what was clearly likely to be rather a specialized group are recognized: however, given that the purpose of the study was to develop areas for further exploration, and in the light of other time and funding constraints which made a definitive study not feasible, this strategy seemed acceptable. Moreover, we found that in many respects the profiles of respondents were similar to those found in other, larger studies. These similarities, which are noted where relevant, give us reason to believe that our sample can offer useful insights into the roles and responsibilities of male foster carers.

\section{Methodology}

A postal questionnaire was sent, in early autumn 2004, to every foster father registered with the fostering agency. Respondents were also asked at the end of the questionnaire 
if they would be willing to be interviewed. 30 initially indicated a willingness to be contacted for interview. Nine of these were, in the event, available during the two days of planned interviewing, which took place at two of the fostering agency's offices.

Of the 118 foster fathers who were sent a copy of the questionnaire, 69 returned a completed form. This gives a response rate of $58 \%$, which is lower than has been achieved in other surveys of foster carers (e.g. Triseliotis et al, 2000; Sinclair et al, 2004; Hojer, 2004). This may arguably be a reflection of the extent to which some (but, as we shall see, by no means all) foster fathers regard fostering as primarily an undertaking of their female partner, or at least that the main responsibility for negotiations with the external world around fostering lies with the foster mother. In the Triseliotiset al study, for example, which achieved a 74\% return, 53\% were completed jointly by female and male carers, and the remainder predominantly by females. From the information available to us, characteristics of respondents and non-respondents in our study seemed broadly similar (e.g. in experience of fostering, marital status and ethnicity). However, we have no way of knowing if the non-responders' answers to crucial questions about fostering roles and tasks undertaken would have resembled those who did reply.

\section{Profile of respondents}

In general, the large-scale studies already discussed have suggested that foster families are rather more 'conventional' than others in the general population They are more likely, for example, than comparable families to have two parents, one of whom goes out to work. In keeping with this, the majority (90\%) of foster fathers in this study were married, the remainder (10\%) were all co-habiting with female partners and there were no single male carers. Relationships tended to be of lengthy duration, averaging 20 years together (and thus showing greater stability than couples in the general population.) Most respondents were in their middle years, with an age profile similar to that reported by Gray and Parr (1957), Bebbington and Miles (1990), Triseliotis et al (2000) and Sinclair et al (2004) who found, as we did, that most were aged between 31 and 60, with the male carers being slightly older than females. Respondents were predominantly experienced carers, having previously fostered a mean average of 9.8 children - a figure which rose to 12.6 children when foster carers awaiting their first placement were excluded from the calculation. 
It was perhaps unsurprising that, in comparison to average families, foster families contained more children. At the time the survey was undertaken the median average number of children per household (foster children and other children) was 3 . However, one third of households (34\%) contained four or more children. This may be a relevant factor in whether or not male foster carers take an active role in parenting: it is arguable that, with adults outnumbered by children, men in families who foster simply do not have the option of just 'sitting on the sidelines'. Although she does not make an explicit link to the number of children in a fostering household, Hojer, 2004, asserts that fostering 'draws males to the centre of family life'. p.42

All of the foster fathers described themselves as heterosexual. The self-reported incidence of disability amongst this group of foster carers was low: just 3\% of male foster carers (two individuals) and 1\% of their female partners (one individual). The proportion of both male and female carers describing themselves as coming from a minority ethnic group was also low. The vast majority of male foster carers (90\%) described their ethnicity as being White English or White British: others described themselves as White European (6\%) or as of a specific European background (e.g. Dutch or Irish). None described themselves as black or Asian. Their partners were similarly mostly described as White English or White British (90\%). These figures are broadly similar to those found by other studies undertaken in areas where the ethnic population is low (e.g. Sellick \& Connolly, 2002; Sinclair et al, 2004) and suggest that difficulties may arise if a child from a minority ethnic group needs to be fostered. However, ethnicity was not a key concern of this study.

\section{Foster fathers' experiences}

We now turn to consider three particular aspects of the foster fathers' experiences, namely recruitment and routes into fostering, employment and the related issue of finance, and finally foster fathers' roles and tasks. We focus on these both because they have been identified in the literature as key themes, and because they are relevant to increasing our understanding of foster fathers' contribution to fostering more generally. 


\section{Becoming involved: recruitment}

Concern about the supply of foster carers inevitably puts a focus on the recruitment of foster carers; a growing body of literature has highlighted the effectiveness or otherwise of a variety of recruitment systems (Hill, 1999, Triseliotis et al, 2000, Wilson et al, 2004). Judging from the literature however, rather less attention seems to have been paid to the part men may play in this. Yet evidence from our study suggests that, although rarely instigating the idea of fostering, many men took an active part in the process of deciding to foster. It seems plausible therefore that their willingness or otherwise to be involved is a significant factor in the ultimate decision.

Survey respondents were asked how they had first come to consider the possibility of becoming a foster carer. All were able to recall where the idea of fostering had come from. In almost half of cases (48\%) it was the man's partner who had first suggested fostering, in a further third of cases $(36 \%)$ it was a joint idea and in a minority of cases (7\%) the idea had been initiated by the foster father himself. A full breakdown of replies to this question is shown in table 1. Interestingly, these proportions are broadly similar to those in Triseliotis et al's 2000 study, a finding which suggests that the initial motivation to foster may be unconnected to later decisions about which fostering agency to apply to.

\section{Table 1 here}

Our interviewees further illuminate some of the processes involved in embarking on becoming foster carers. In a number of the cases, either one or both of the partners had had some previous familiarity with fostering, either dating from childhood or from friends and relations' own involvement. Interestingly, in this (albeit very small) group, it tended to be the men rather than their wives who had had previous contact:

We'd talked about it for years, and I mean years, before we had our first two boys. And my parents used to foster, so it came from that, and my wife was a single child .. and we wanted more children around. 
I was brought up in a family where my parents fostered, so that was one thing, although it wasn't a particularly good experience for me, that was... that happened, so that was part of my childhood.

The interviews also convey the fact that while one or other of the partners may have had the original idea or experience, taking the idea forward became a shared process:

I think initially, the initial drive sort of came from me, insomuch as 'yeah, this is something that I want to do', and Mary, my wife, .... she is a very caring person, as well, and so I think in one sense, we thought, 'yeah, we can do this', you know.

My wife, Glenda, she was the one that sort of shoe-horned us into it, really. Although at the time I was a registered child-minder, so it was sort of a natural progression, if you like. So it came at a time when my career was all upsidedown anyway, so it sort of seemed to fit the bill.

As other studies have done, ours too demonstrated the variety of motives which brought carers into fostering. These commonly included the conviction that they had something worthwhile to offer, in particular an experience of family life which could be of value to a deprived child: 'we felt we had a happy home which we could put to help children who hadn't had one'. For some, as with the carer above, who thought it would provide companionship for their daughter, or another carer who saw it as a means of preventing his youngest becoming spoiled by too much attention, fostering seemed to offer a fit with their own family's needs. For others, too, as in one of the examples above, the idea came along at a time when they were considering, or were obliged to consider, a career change (an issue we return to below.)

Significantly, for a number of respondents, the feeling of 'something to offer' crystallized around the idea that, as men, their contribution could have a particular value:

And I just felt that it would be great, almost to bring your work home with you, and actually do something to support kids - especially boys, who I think struggle 
with finding positive male role models. They need, you know, good, solid figures in their lives, who can actually inform their lives, and help them to make more sensible choices in life, really.

I just thought, as a man, you could offer a safe and secure home to that child, as a new role model, which may help them change what they know, or what they think, about men.

Some particularly valued being singled out during the recruitment phase as having something important to offer:

Again, it was nice that, being a guy coming from a very sort of female-orientated area, meeting another guy who was very, very pro. You know, 'we need more guys here'. We almost signed up on the spot, really, with them.

They seemed more centred round me, because I was a male, and I was interested...

Steve [social work trainer] was very much about, 'you know, it needs to be a partnership more, you know, so we need more guys involved'. And that was what swung it for me, really, here. Because it was more pitched towards, you know, 'we want guys here, we want guys working'.

By contrast, one foster father commented on the 'gender blindness' of the trainer on his induction programme.

The female social worker did the training, and she said, 'now I'm going to pass you over to a very hunky policeman who's going to tell you all about the police procedure', and I was like, 'excuse me! I don't find him hunky at all!' 'Well, you're a man!' [laughs] And that has kind of stuck in my head, the way she didn't get that hint-you did get some saying, 'well, obviously, child care is very female - as long as you look after the missus, and take them on holiday, and do all that sort of stuff, then it'll be great.' 
Fortunately, as he added, another - male - trainer had balanced this negative perception later:

It was all about, you know, 'you need to get involved, even you guyswho go to work, you'll be involved'. That's what I liked.

\section{Staying involved: employment and income}

Other studies have highlighted the significance of the relationship between fostering and employment and finance in encouraging carers to enter and remain as foster carers (Kirton et al, 2004). Sinclair and colleagues (2004) suggest that turnover in fact is quite low, (about $10 \%$ a year in their study were reported as leaving the service) and that a number of those leaving do so for reasons which may have more to do with inevitable 'life stages', such as retirement, than be amenable to influence. Nonetheless they also argue that the relationship of fostering to work outside the home, how fostering fits in with carers' other employment and its financial rewards are important issues in delivering a successful service. With this in mind, we wanted to explore the impact of fostering on men's employment, and their perceptions of its financial rewards.

\section{Employment}

The amount of paid employment (excluding the work of fostering itself) varied both amongst foster fathers and between the male survey respondents and their female partners. The majority $(72 \%)$ of male foster carers worked full-time, with a small number working part-time (16\%) and a few (12\%) describing themselves as full-time foster carers. By contrast, almost half of the men's female partners (48\%) were described as full-time foster carers, with $38 \%$ of women working part-time and only $13 \%$ in full-time employment. This gender gap was even more marked when comparing those who worked long hours (over 40 hours per week). Almost two-fifths (39\%) of foster fathers worked for over 40 hours each week, with 13\% working over 50 hours per week, but only one woman worked more than 40 hours per week. Full details are shown in table 2.

Table 2 here 
There were exceptions to the traditional family model, however, the most notable being those men $(12 \%)$ who described themselves as full-time foster carers. Of these eight families, four were couples who both fostered full-time; in two cases the female partner worked part-time and in two cases the female partner worked full-time. In those cases where the female partner was in full-time employment, both men stated that their hours of work had not changed since starting to foster, implying that they had been 'house husbands' prior to becoming foster fathers. With respect to the other six men who now fostered full-time: three had retired, one had sold a care business and two had given up paid employment in order to foster.

The experience of fostering also played a part in changing the work patterns of some men. Although the majority of respondents (57\%) said that the type or amount of paid work that they did had not changed since becoming a foster carer, over four in ten had either reduced their hours, or had moved to become full-time carers. This came about, for some, because the satisfaction of fostering gradually drew them to participate more fully in caring for the children.

So I gradually found myself doing more with the kids, and then it made sense to cut down on my job outside, and that's what I've done.

Well, I was full time, and I wasn't happy with not being there, and not going... you know, I didn't like all this 'can I speak to your wife?', 'is your wife there?', because you're almost never there. So I said, 'right, I'm going to go part time.' Which is what I did, and I only do 24 hours a week, so I'm there six, seven hours through the day, and get quite involved with whatever's going on, really, which is what we wanted to do.

Where this had happened, the move had been made possible at least in part by the fostering allowances, which were seen by all nine interviewees as 'fair'- 'very good''very generous actually'.

\section{Income}

The household incomes of survey respondents (excluding any allowances received for fostering) tended to be lower than average, particularly considering that this research 
was undertaken in southeast England - where typical incomes are higher than in other parts of the country. The majority (53\%) of respondents had annual household incomes of $£ 25 \mathrm{k}$ or less; one third (33\%) had annual household incomes of $£ 20 \mathrm{k}$ or less; and $14 \%$ of respondents had an annual family income of less than $£ 15 \mathrm{k}$. The range of family incomes is shown in table 3 .

\section{Table 3 here}

However, when allowances paid for fostering are taken into account, family incomes were boosted significantly. The agency paid a flat rate of $£ 335$ per foster child, per week. Where carers had three foster children placed with them, this is equivalent to $£ 1,005$ per week - or $£ 52,260$ per year - of largely untaxed income; for two or one foster child the figures are $£ 34,840$ per annum and $£ 17,420$ per annum respectively. However, it should also be noted that foster carers receive no payment if they do not have a child placed with them. Income from fostering may therefore fluctuate considerably over time, especially if placements are short-term. Respondents to the questionnaire were not asked how satisfied they were with remuneration for fostering, but comments from interviewees suggest that the income from fostering is one of the factors in their readiness to continue fostering. Moreover, the majority of interviewees agreed that the allowances enabled them to live quite comfortably.

I didn't know, when I went into fostering, that you got paid for it, as a proper, paid job. I thought you just got fifty quid a week clothing allowance - that's what my sister used to get, because she did it for the local authority. But I can live with two... I can earn a living with two children, or more, quite comfortably.

And to be honest, you know, it provides us with quite a nice standard of living, without having to go to a normal job.

It has allowed me to ease up my work hours so I have much more quality time with our foster children. It has been quite life challenging, and although we probably live on less money it has allowed me to get to know my own children and those fostered better. 


\section{Staying involved: roles and tasks}

Finally, we consider the contribution which foster fathers see themselves as making to the lives of their foster children, and to their family life more generally. There are two main issues to be considered here. Firstly, what part fathers play in caring for their foster children, and secondly whether or not there is anything which men contribute by virtue of their gender. Is there, for example, some quality which arises from being men, which another, female, adult could not contribute? In what follows, of course, it is important to remember that these are male perceptions of their roles and tasks and might not reflect their partners' views.

\section{The tasks associated with fostering}

Survey respondents were asked to rate whether they or their female partner took greater responsibility for a wide range of tasks associated with fostering. (The tasks, 52 in all, were largely derived from those used in other foster care studies, including a set of twelve questions developed by Marjorie Smith and used by Sinclair and colleagues to measure a quality of carers' child orientation. See Sinclair et al, 2005, pp188-190 for fuller discussion.) The results, shown below, divide the tasks into three broad categories. The first category, with 13 tasks, include liaising with organisations or individuals outside the home; the second category involves 7 tasks which could be broadly labelled as household chores; and the final category list 32 tasks directly connected to meeting the needs of foster children.

Tasks for which the majority of foster fathers said they took main responsibility are shown in bold and those where female partners bore the biggest burden are italicised. Tasks where there was no overall majority are left in ordinary type.

\section{Table 4 here}

Female partners took as much as or more responsibility for most of these tasks than men. The only exception to this was "contact with police and/or courts", where men were marginally more likely to take the main responsibility in this area. More broadly, it was noticeable that tasks relating to general "contact" with officialdom tended - on average - to be the preserve of female partners, whereas tasks that involved "attending" specific events were more often shared equally. This may suggest that, in many homes, 
female partners take responsibility for dealing with day-to-day issues arising (e.g. contact with a child's social worker, or appointments with the child's GP), and that foster fathers involve themselves to a greater extent in pre-planned events (e.g. foster care reviews, or school parents' evenings).

\section{Table 5 here}

In relation to household chores, there was clear evidence of a 'traditional' gendered division of labour. Men were more likely to take the lead role in relation to gardening and DIY, but in all other respects women were taking the lead in everyday household chores.

\section{Table 6 here}

There is some further evidence for the gendered division of labour within the tasks relating to direct involvement with children. However, what is arguably of greater note is that the majority of these tasks (20 out of 31 ) were judged to be shared about equally between male respondents and their partners. Notably, those parenting tasks which promote attachment, either by providing security and comfort, developing autonomy or modifying behaviour (Heard \& Lake, 1997) seem to be carried out more or less equally by male and female foster carers. Since these tasks are likely to be highly relevant to successful fostering outcomes, the fact that the men in our study perceived these tasks to be as much their responsibility as their partners' provides support for the centrality of their role in the fostering relationship.

Our interviewees, (perhaps predictably since they were a self-selected group likely to be highly committed to fostering) largely reflected the picture of joint involvement and shared responsibility:

But I guess if we were to write it all down, which we've never done, because we never do that, but I guess it's very evenly balanced.

I think we probably are fairly equal, actually. Because I guess I probably spend as much time - although I do go through phases when I'm not at home, for 
work. But I generally sort bedtimes out, and I always wake them up in the mornings, because I'm always the first one up.

Only one interviewee felt that he took a clearly secondary role, seeing this however as a reflection of the dynamics of their relationship more generally than specifically related to fostering:

Yeah, I think just because of the way that we are, Doreen takes the lead role in the majority of things, so I think that just was a natural. But not only with the fostering, I think with most things, Doreen is in the forefront of it, I think.

All gave examples of activities which they undertook, sometimes with their partners, sometimes on their own, with the foster children. Many of these fell into a stereotypically male category:

I tend to do more activities with the children, although we do do quite a lot as a whole family. This morning I was taking the 16-year-old boy out to buy a keepfit workbench which he'd wanted. I like taking them all fishing, the boys, all have gone fishing, to see if they like it or not, and different sports events.

But the activities were mostly seen not just as an opportunity for having fun, important though this was - sometimes we just lark around - but as a chance to develop confidence, build relationships and so on:

Take them for walks, hold their hands. They'd never had this, and it was very, very strange for them. And it was a very positive thing to do, for them and for us, at the time. ...

A good example, the other day, is that my car has a water leak, or did have a water leak. They're easy to fix and find, but Ricky... wanted to know how you fix water leaks in the car. So he came out, and I showed him. And again, that's the teacher in me, I guess. I quite enjoyed doing that, because he was a willing participant, and he wanted to do it. And I just enjoy having conversations with him at night, just sitting and watching telly 
Most interviewees felt that, as couples, they had adopted their roles relatively unconsciously - we didn't really ever discuss it. However, some described approaching their division of labour more deliberately, actively attempting to counteract stereotypes:

If there's an element of sexism creeping into any of the children, we switch roles. Katie will do the car, and I'll wash up. I'll cook - I cook anyway, and again, the boys enjoy cooking. ... a good example is that one day Katie stripped down the computer and put in a new bit. 'What are you doing? Stewart does that.' 'I can do this as well.' 'Does he know?' [laughs] 'He's there, look, he's watching me!' [laughs] 'Oh, is he checking up?' And we did mix it up a lotwe'd have a rota, actually, for household chores. And cooking is a chore! If I cook, that's a chore, so you wash up, K cooks, I Hoover, stuff like that.

Finally, all of the men interviewed considered that, as foster fathers, they had a specifically male contribution to make. One described the flexibility that having different genders provided:

Some girls will prefer to come and talk to a male about problems. We had a 14year-old teenage girl that couldn't get on with her stepdad. And she used to come and talk to me, and ask why there was such a difference between him and myself, but wouldn't talk to the wife about it. So yeah, it depends on the child.

Some felt that there were issues to do with male behaviour which only a man could effectively deal with:

I'm trying to teach him that you can't do that, ever, at all. But he hasn't grasped it yet! And I think that's a positive thing, because it's all right for a woman to say, 'you mustn't hit women', or 'you mustn't hit anybody, but you especially don't hit women', but they would say that, wouldn't they? In his eyes, he'd think, 'well, you're just saying that because you're a woman.' It needs a man to say that. 
Yet others, as we described earlier in the article, felt it important to provide a benign, counter picture of what fathers were like:

I think they can offer them the same things, but they [the children] might think that women are generally $O K$, and men are generally not $O K$. So if they are looked after by a man, or at least partly looked after by a man, who is OK, then if there's one man in the world who's OK, then there must be more. So they can't all be bad. If that's a child who's had bad experiences with men.

We felt that it was best for me to actually go and sit and play with the children, and show them that not all males were... could do them harm. Sit there and read to them, and cuddle them - because they'd never been cuddled by anybody apart from a female

Interestingly, even the interviewee who said firmly that he did not consider any distinction should or could be made between male and female parenting went on to give an example of a boy who had indeed gravitated towards him.

\section{Discussion}

The study does, we think, provide evidence to support, albeit tentatively, the views of those who assert the importance and distinctiveness of the foster father's role. First, it is clear from our study that men do indeed play a part, often an active one, in the decision to foster. Getting more of an understanding of what prompts foster fathers to foster, who they are and how they perceive and manage the role may be a means of tapping into an additional pool of foster carers. So the foster fathers' motivation to foster, what they see as its positives and drawbacks, and how it fits into their own family lives are all relevant to improving service recruitment, delivery and retention. In addition to ensuring awareness of the impact of training materials, styles and so on, it might be sensible to do more actively and specifically to recruit men. There was some suggestion that the positive identification and encouragement given to men in the first stages of recruitment was a significant factor in the couple's decision to become foster carers, and that it helped to meet male recruiters and trainers (Newstone 2005). 
Second, the fostering allowances (together with the current tax arrangements) were in general seen as satisfactory, so that the relationship with employment, and managing fostering in relation to outside work, generally seemed to work well. How much this contributed to the sense communicated in questionnaires and interviews of relative contentment with the role is unclear, but it is reasonable to assume it helped. For our sample at least, the critical relationship between fostering, employment and adequate remuneration seemed to be satisfactory.

Finally, the study produced some evidence about the kind of contribution that foster fathers see themselves making to the lives of the children they foster. This provided insight into foster father's perceptions of the roles which they fulfilled, both with foster children in particular and within the household more generally. Broadly speaking, it appeared that foster fathers tended to take the lead in relation to only a small number of what might be termed traditional masculine roles - such as DIY and watching sports. In comparison, there were a greater number of roles which were predominantly undertaken by female foster carers - including contact with schools, social services and the fostering agency; cooking, shopping and laundry; bathtime, teaching self-care skills, nursing poorly children. However, the majority of tasks were judged to be shared equally between male and female foster carers. This was true of many activities which might, in previous generations, have been regarded as part of the 'mothering' role, and included tasks such as household cleaning; attending school parents' evenings; reading bedtime stories; comforting an upset child; helping with homework; and talking to children about any problems, fears or worries they might have.

It was evident that many foster fathers were actively trying to support their foster children in a gender-neutral manner and, by doing so, to act as a positive male role model. Foster fathers were, for the most part, eager to embrace both the practical and emotional aspects of foster caring: they were aware that many foster children have a history of difficult relationships with men (birth fathers, mothers' partners) and believed it to be important that they taught by their actions, that men were capable of relating well to both children and to their wives or partners.

In thinking about how we can develop services to become more attuned to addressing the diverse range of foster children's needs, we need to refine our ideas about the role of 
foster fathers. We do not in fact know if it is, as some of the literature on 'ordinary' fathers suggests, the presence of two committed adults who can provide parenting which is crucial, rather than gender differences per se (Lamb, 2004). It may be that foster care in fact requires a more conscious kind of parenting, one where gender does play a part. For example, with children who are likely to have been abused, does the presence of a benign male offer an important alternative model, which less needy children do not require? As we have seen, many of the fathers in our study see this as the case.

Fathers, at least as they conceived their roles, participated in a majority of the tasks involving direct work with children more actively than might have been predicted. Our interviewees considered that, as men, they had a distinctive and positive contribution to make in helping troubled children resolve their difficulties. Further research is needed to refine our knowledge of what this contribution may be. Such knowledge could potentially develop our understanding of the roles of fathers in child development more generally as well as fine-tuning practice in matching what particular placements have to offer to the needs of individual children.

Note: All names and some identifying details from respondents have been changed. 


\section{References}

Bebbington A, Miles, J. 1989. The Background of Children who Enter Local Authority Care, British Journal of Social Work, 19: 5, pp 349-368

Fanshel, D and Shinn, E (1978) Children in foster care: a longitudinal study. New York: Columbia Press.

Gilligan, R. 2000. Men as Foster Carers: A Neglected Resource? Adoption and Fostering, 24: 2, pp 63-69

Gray, P and Parr, E (1957) Children in Care and the Recruitment of Foster Carers. London: Home Office

Heard, D and Lake, B (1997) The Challenge of Attachment for Caregiving. London: Routledge.

Hill, M. ed.(1999) Signposts in fostering. London: BAAF

Hojer, I.(2004) 'What Happens in the Foster Family?’ Adoption and Fostering, 28: 1, pp 38-48

Inch, L (1999) 'Aspects of foster fathering'. Child and Adolescent Social Work Journal, 16,5 , pp 393-412.

Kirton, D, Beecham, J and Ogilvie, K (2004) 'Remuneration and Performance in Foster Care. Report to Department for Education and Skills.' Canterbury: University of Kent.

Lamb, M, ed, (2004) The Role of the Father in Child Development, $4^{\text {th }}$ edition. New Jersey: John Wiley and Sons

Newstone, S. (2000) 'Male Foster Carers: What do we mean by 'Role Models'?' Adoption and Fostering, 24: 3, pp 34-47 
Newstone, S (2005) 'Men as foster carers'. In: Companion to foster care (ed. A. Wheal) London: Russell House Publishing. $2^{\text {nd }}$ edition

Sellick, C and Connolly J (2002) 'Independent fostering agencies uncovered: the findings of a national study.' Child and Family Social Work. Volume 7, Number 2, pp 107-120.

Sinclair, I, Gibbs, I and Wilson, K.(2004) Foster carers: why they stay and why they leave. London Jessica Kingsley

Triseliotis, J, Borland, M, Hill, M.(2000) Delivering Foster Care. London: BAAF

Wilson, K, Sinclair, I, Taylor, C, Sellick, C and Pithouse, A (2004) Fostering Success: an exploration of the research literature on foster care. London: Social Care Institute for Excellence. 
Table 1: Whose idea was it to start fostering?

\begin{tabular}{|l|c|}
\hline & Percentage* \\
\hline Man's idea & $7 \%$ \\
\hline Female partner's idea & $36 \%$ \\
\hline Joint idea & $48 \%$ \\
\hline Suggested by other foster carers & $10 \%$ \\
\hline Can't remember & $0 \%$ \\
\hline Other & $4 \%$ \\
\hline
\end{tabular}

(* total percentage is more than 100 as some respondents gave more than one response)

Table 2: Hours per week of paid employment

\begin{tabular}{|l|c|c|}
\hline & Foster fathers & Female partners \\
\hline None (i.e. full-time foster carer) & $12 \%$ & $48 \%$ \\
\hline $1-10$ & $3 \%$ & $13 \%$ \\
\hline $11-20$ & $4 \%$ & $16 \%$ \\
\hline $21-30$ & $9 \%$ & $9 \%$ \\
\hline $31-40$ & $33 \%$ & $13 \%$ \\
\hline $41-50$ & $26 \%$ & $0 \%$ \\
\hline $50+$ & $13 \%$ & $1 \%$ \\
\hline
\end{tabular}

Table 3: Annual household income (excluding fostering allowances)

\begin{tabular}{|l|c|}
\hline & Percentage \\
\hline Did not say & $6 \%$ \\
\hline Under $£ 15 \mathrm{k}$ & $14 \%$ \\
\hline$£ 15-20 \mathrm{k}$ & $19 \%$ \\
\hline$£ 21-25 \mathrm{k}$ & $20 \%$ \\
\hline$£ 26-30 \mathrm{k}$ & $14 \%$ \\
\hline$£ 31-40 \mathrm{k}$ & $10 \%$ \\
\hline$£ 41-50 \mathrm{k}$ & $9 \%$ \\
\hline Over $£ 50 \mathrm{k}$ & $7 \%$ \\
\hline
\end{tabular}


Table 4: Liaising with organisations $\&$ individuals out side the home

\begin{tabular}{|l|c|c|c|c|}
\hline & $\begin{array}{l}\text { A mostly } \\
\text { male task }\end{array}$ & $\begin{array}{l}\text { Task } \\
\text { shared } \\
\text { equally }\end{array}$ & $\begin{array}{l}\text { A mostly } \\
\text { female } \\
\text { task }\end{array}$ & $\begin{array}{l}\text { Didn't } \\
\text { say/task not } \\
\text { relevant }\end{array}$ \\
\hline Contact with fostering agency & $6 \%$ & $30 \%$ & $61 \%$ & $3 \%$ \\
\hline Contact with social services & $6 \%$ & $26 \%$ & $65 \%$ & $3 \%$ \\
\hline Contact with schools & $12 \%$ & $29 \%$ & $55 \%$ & $4 \%$ \\
\hline $\begin{array}{l}\text { Contact with GP \& other health } \\
\text { professionals }\end{array}$ & $4 \%$ & $22 \%$ & $71 \%$ & $3 \%$ \\
\hline $\begin{array}{l}\text { Contact with child's biological } \\
\text { family }\end{array}$ & $6 \%$ & $49 \%$ & $30 \%$ & $14 \%$ \\
\hline Contact with police and/or courts & $22 \%$ & $25 \%$ & $19 \%$ & $35 \%$ \\
\hline Attend foster carer annual reviews & $4 \%$ & $72 \%$ & $17 \%$ & $6 \%$ \\
\hline Attend child care reviews & $3 \%$ & $61 \%$ & $30 \%$ & $6 \%$ \\
\hline Attend foster care training events & $6 \%$ & $59 \%$ & $28 \%$ & $7 \%$ \\
\hline Attend fostering support group & $7 \%$ & $41 \%$ & $39 \%$ & $13 \%$ \\
\hline $\begin{array}{l}\text { Attend fostering agency social } \\
\text { events }\end{array}$ & $1 \%$ & $84 \%$ & $9 \%$ & $6 \%$ \\
\hline Attend school parents' evenings & $7 \%$ & $46 \%$ & $35 \%$ & $12 \%$ \\
\hline Attend other school events & $4 \%$ & $41 \%$ & $38 \%$ & $17 \%$ \\
\hline
\end{tabular}

Table 5: Household chores

\begin{tabular}{|l|c|c|c|l|}
\hline & $\begin{array}{l}\text { A mostly male } \\
\text { task }\end{array}$ & $\begin{array}{l}\text { Task shared } \\
\text { equally }\end{array}$ & $\begin{array}{l}\text { A mostly } \\
\text { female task }\end{array}$ & $\begin{array}{l}\text { Did not } \\
\text { say/task not } \\
\text { relevant }\end{array}$ \\
\hline Cooking & $9 \%$ & $20 \%$ & $66 \%$ & $4 \%$ \\
\hline Laundry \& ironing & $4 \%$ & $19 \%$ & $74 \%$ & $3 \%$ \\
\hline Supermarket shopping & $14 \%$ & $33 \%$ & $49 \%$ & $3 \%$ \\
\hline $\begin{array}{l}\text { Clothes shoppingfor } \\
\text { children }\end{array}$ & $3 \%$ & $20 \%$ & $72 \%$ & $4 \%$ \\
\hline
\end{tabular}




\begin{tabular}{|l|c|c|c|c|}
\hline Household cleaning & $7 \%$ & $42 \%$ & $42 \%$ & $9 \%$ \\
\hline Gardening & $42 \%$ & $35 \%$ & $20 \%$ & $3 \%$ \\
\hline DIY \& decorating & $\mathbf{7 8 \%}$ & $12 \%$ & $6 \%$ & $4 \%$ \\
\hline
\end{tabular}

Table 6: Directly child-related tasks

\begin{tabular}{|c|c|c|c|c|}
\hline & $\begin{array}{l}\text { A mostly } \\
\text { male task }\end{array}$ & $\begin{array}{l}\text { Task } \\
\text { shared } \\
\text { equally }\end{array}$ & $\begin{array}{l}\text { A mostly } \\
\text { female } \\
\text { task }\end{array}$ & $\begin{array}{l}\text { Did not } \\
\text { say/task } \\
\text { not } \\
\text { relevant }\end{array}$ \\
\hline Bathing younger children & $1 \%$ & $28 \%$ & $54 \%$ & $14 \%$ \\
\hline $\begin{array}{l}\text { Teaching self-care skills (e.g. } \\
\text { dressing) }\end{array}$ & $1 \%$ & $35 \%$ & $51 \%$ & $10 \%$ \\
\hline Nursing a poorly child & $1 \%$ & $41 \%$ & $49 \%$ & $9 \%$ \\
\hline $\begin{array}{l}\text { Taking time off work to nurse a } \\
\text { poorly child }\end{array}$ & $0 \%$ & $16 \%$ & $51 \%$ & $33 \%$ \\
\hline $\begin{array}{l}\text { Arranging to have a child's friends } \\
\text { over to play }\end{array}$ & $4 \%$ & $20 \%$ & $65 \%$ & $10 \%$ \\
\hline $\begin{array}{l}\text { Arranging parties/other special } \\
\text { celebrations }\end{array}$ & $3 \%$ & $25 \%$ & $65 \%$ & $7 \%$ \\
\hline Handing out pocket money & $9 \%$ & $38 \%$ & $48 \%$ & $6 \%$ \\
\hline Visiting a library & $1 \%$ & $30 \%$ & $43 \%$ & $25 \%$ \\
\hline $\begin{array}{l}\text { Talking about sex \& relationships - } \\
\text { with girls }\end{array}$ & $3 \%$ & $33 \%$ & $48 \%$ & $16 \%$ \\
\hline Reading bedtime stories & $6 \%$ & $48 \%$ & $26 \%$ & $17 \%$ \\
\hline Comforting an upset child & $1 \%$ & $68 \%$ & $23 \%$ & $4 \%$ \\
\hline Helping with homework & $10 \%$ & $61 \%$ & $22 \%$ & $7 \%$ \\
\hline $\begin{array}{l}\text { Helping to maintain child's } \\
\text { friendships }\end{array}$ & $1 \%$ & $52 \%$ & $36 \%$ & $10 \%$ \\
\hline Driving child to and from activities & $23 \%$ & $59 \%$ & $10 \%$ & $7 \%$ \\
\hline $\begin{array}{l}\text { Praising/rewarding child for good } \\
\text { behaviour }\end{array}$ & $0 \%$ & $87 \%$ & $9 \%$ & $4 \%$ \\
\hline $\begin{array}{l}\text { Talking through any behaviour } \\
\text { problems }\end{array}$ & $7 \%$ & $78 \%$ & $12 \%$ & $3 \%$ \\
\hline
\end{tabular}




\begin{tabular}{|l|c|c|c|c|}
\hline Imposing discipline or sanctions & $10 \%$ & $75 \%$ & $12 \%$ & $3 \%$ \\
\hline $\begin{array}{l}\text { Negotiating boundaries (e.g. how } \\
\text { late a teenager can stay out) }\end{array}$ & $6 \%$ & $81 \%$ & $4 \%$ & $9 \%$ \\
\hline $\begin{array}{l}\text { Talking about sex \& relationships - } \\
\text { with boys }\end{array}$ & $19 \%$ & $38 \%$ & $17 \%$ & $25 \%$ \\
\hline $\begin{array}{l}\text { Talking to child about their fears or } \\
\text { worries }\end{array}$ & $4 \%$ & $71 \%$ & $22 \%$ & $3 \%$ \\
\hline $\begin{array}{l}\text { Talking to child about their } \\
\text { biological family }\end{array}$ & $4 \%$ & $65 \%$ & $23 \%$ & $7 \%$ \\
\hline $\begin{array}{l}\text { Attending a place of worship (e.g. } \\
\text { church; mosque) }\end{array}$ & $4 \%$ & $36 \%$ & $13 \%$ & $46 \%$ \\
\hline Going to the local park & $14 \%$ & $54 \%$ & $13 \%$ & $19 \%$ \\
\hline $\begin{array}{l}\text { Playing games (e.g. snakes \& } \\
\text { ladders) }\end{array}$ & $4 \%$ & $64 \%$ & $17 \%$ & $14 \%$ \\
\hline $\begin{array}{l}\text { Playing sports (e.g. swimming, } \\
\text { football) }\end{array}$ & $25 \%$ & $49 \%$ & $7 \%$ & $19 \%$ \\
\hline Going to cinema/theatre/pantomime & $3 \%$ & $71 \%$ & $14 \%$ & $12 \%$ \\
\hline Educational days out (e.g. museum) & $1 \%$ & $64 \%$ & $16 \%$ & $19 \%$ \\
\hline Fun days out (e.g. theme park) & $3 \%$ & $94 \%$ & $3 \%$ & $13 \%$ \\
\hline $\begin{array}{l}\text { Taking child on holiday } \\
\text { Watching sports (e.g. football }\end{array}$ & $33 \%$ & $6 \%$ & $20 \%$ \\
\hline
\end{tabular}

